\title{
DETECTION OF NARCISSUS LATENT VIRUS ISOLATES USING ONE-STEP RT-PCR ASSAY
}

\author{
Hanna BERNIAK*, Beata KOMOROWSKA, Dariusz SOCHACKI \\ Research Institute of Horticulture \\ Konstytucji 3 Maja 1/3, 96-100 Skierniewice, Poland \\ Received: January 14, 2013; Accepted: May 30, 2013
}

\begin{abstract}
A one-step RT-PCR procedure was developed for specific detection of Narcissus latent virus (NLV) isolates. Following alignment of RNA sequences of three NLV isolates, the conserved sequence fragments were identified in viral polyprotein gene and 3'UTR region. Based on those fragments, a forward NLs1 and two reverse: NLa1 and NLSCPR2 primers were designed. Primer pairs NLs1-NLa1 and NLs1NLSCPR2 proved to be effective in amplification of a $669 \mathrm{bp}$ and 1295 bp products, respectively. Sequence analysis of amplified products confirmed their specificity.
\end{abstract}

Key words: NLV, virus identification, RT-PCR, DAS-ELISA, narcissus cultivars

\section{INTRODUCTION}

Narcissus latent virus (NLV) is a member of Macluravirus genus of the family Potyviridae. The virus affects commercially important narcissus cultivars (Brunt and Atkey 1967; Brunt 1977; Clark and Guy 2000) and occurs sporadically in other bulbous plants, like iris, gladiolus and nerine (Brunt 1977; Derks et al. 1985; Wei et al. 2007). Our observations indicate that NLV occurs commonly in narcissus plants in Poland both in the field and in in vitro cultures (Sochacki $2011 \mathrm{a}, \mathrm{b}$ ), but there is a little information available confirming the incidence of this virus in narcissus plantations worldwide (Clark and Guy 2000). NLV alone can induce mild leaf chlorosis or transient leaf tip chlorosis in susceptible cultivars, but usually causes inconspicuous or symptomless infection in naturally infected narcissus plants. It is suspected that NLV exacerbates the effects of other viruses with which it occurs in complex (Brunt 1977, Derks et al. 1985). At least 24 other viruses have been reported for Narcissus spp. (Brunt 1995; Asjes 1996). The most devastating viruses of narcissus plants are: Narcissus yellow stripe virus (NYSV), Narcissus white streak virus (NWSV), and Narcissus degeneration virus (NDV) (Hanks 1993). Other common viruses are: Narcissus late seasons yellows virus (NLSYV), Narcissus mosaic virus (NMV), and Cucumber mosaic virus (CMV).

The occurrence of several viruses in narcissus plants as well as the lack of specific and reliable NLV identification system makes NLV detection difficult. Until recently, the virus isolates had been detected using enzyme linked immunosorbent assay (ELISA) tests with polyclonal antibodies. However, application of ELISA assay is limited, because commercial kits for NLV testing are no longer available for sale. Prior to this work, NLV diagnosis by reverse transcription-polymerase chain reaction (RT-PCR) was limited to the use of a broad spectrum Potyviridae assays, followed by amplicon sequencing for virus species identification (Chen $e t$ al. 2001; Wei et al. 2007). In this paper, the development of NLV-specific primer pairs for virus onestep RT-PCR amplification is described.

\section{MATERIALS AND METHODS}

The NLV isolates were collected during the surveys of narcissus plants for virus diseases in 2010-2011. The narcissus plants with virus-like 
symptoms (chlorotic, greyish or necrotic streaks or mottles) originated from narcissus collection of the Research Institute of Horticulture, Skierniewice, Poland (cultivar 'Hawera'), and from two commercial plantations located in central Poland ('Dutch Master' and 'Carlton'). Leaf samples of 10 'Hawera', 20 'Dutch Master', and 20 'Carlton' selected plants were collected twice during growing season (in spring and early summer), whereas bulbs scales of the same plants were sampled in late summer after digging up plants for storing. Leaves and bulbs of non-symptomatic plants of each narcissus cultivar were included as negative controls. The NLV isolate obtained from Bulb Quality Support, Lisse, The Netherlands, was used as a positive control in all experiments. The collected samples were stored at $-70{ }^{\circ} \mathrm{C}$ until used.

The narcissus samples were tested for the presence of viruses by double antibody sandwichELISA (DAS-ELISA). The ELISA reagents for NLV and Narcissus mosaic virus (NMV) detection were obtained from Applied Plant Research Flower Bulb Sector, Lisse, The Netherlands, for Arabis mosaic virus (ArMV) - from Loewe Phytodiagnostica, Sauerlach, Germany, for Cucumber mosaic virus (CMV) - antibodies prepared in Research Institute of Horticulture, Skierniewice, Poland (Berniak et al. 2010), and for potyviruses were from Agdia Inc., Elkhart, IN, USA.

The assays were performed according to the manufacturers' recommendations. The absorbance was measured at $405 \mathrm{~nm}$ with a Ledetect 96 reader (Dynamica GmbH, Salzburg, Austria). The samples were recorded infected when absorbance $\left(\mathrm{A}_{405}\right)$ was at least two times higher than the mean $\mathrm{A}_{405}$ for negative control (Clark et al. 1988).

Three RNA sequences of NLV isolates (AC: U58770, DQ450199, FJ024083), available in GenBank, were retrieved and aligned using Lasergene v. 7.1 software package (DNASTAR, Madison, WI, USA) in order to design virus-specific primers. The most conservative fragments of polyprotein open reading frame as well as 3 ' noncoding region (NCR) were selected as possible primers sites. The designed oligonucleotides were evaluated by the Primer Select program from the Lasergene software package for the presence of the possible secondary structures. The forward NLs1 (5' CCAAGTCTATTCACTGT 3', complementary to positions 416-432 of U588770 sequence used as reference) and two reverse NLa1 (5' GCACC AAATGCACCAATT 3', complementary to positions 1067-1084 of U588770), and NLVCPR2 (5' ACATCGCTAGAATGAGCTTGCC 3', complementary to positions 1689-1710 of U588770) primers were chosen from the set of designed oligonucleotides. The primers were initially tested in RT-PCR using several samples of narcissus 'Hawera' known to be NLV-infected.

Total nucleic acids (TNA) were isolated from about $300 \mathrm{mg}$ of leaves or bulbs slices, using silica capture method described originally by Boom et al. (1990) and adapted to the diagnostics of plant viruses by Malinowski (1996).

RT-PCR was carried out using Transcriptor One Step RT-PCR Kit (Roche Diagnostics, Mannheim, Germany). The 50- $\mu 1$ reaction mixture contained $5 \mu \mathrm{l}$ of the TNA, $0,4 \mu \mathrm{M}$ of each primer, $1 \mu 1$ of Transcriptor enzyme mix and $1 \times$ RT-PCR reaction buffer (containing $1.5 \mathrm{mM}$ of each dNTPs). The optimal annealing temperature $\left(\mathrm{T}_{\mathrm{an}}\right)$ for designed primer pairs was established as $52^{\circ} \mathrm{C}$ in a series of preliminary experiments on a Bio-Rad $\mathrm{C} 1000^{\mathrm{TM}}$ Thermal Cycler with gradient block. The optimized cycling parameters were: $30 \mathrm{~min}$ of reverse transcription at $45^{\circ} \mathrm{C}, 7 \mathrm{~min}$ of initial denaturation at $94^{\circ} \mathrm{C}$ followed by 35 cycles consisted of denaturation at $94{ }^{\circ} \mathrm{C}$ for $10 \mathrm{~s}$, annealing at $52{ }^{\circ} \mathrm{C}$ for $30 \mathrm{~s}$, extension for $1 \mathrm{~min}$, and final extension for 7 min at $68^{\circ} \mathrm{C}$. The PCR products $(5 \mu \mathrm{l})$ were separated on $1 \%$ TBE-agarose gels and visualized under UV light after staining with ethidium bromide.

In order to verify the specificity of the amplicons, the purified PCR products were sequenced directly using the same primers as for the original RT-PCR. The sequence alignments and analyses were performed using Lasergene software. Sequence comparisons were performed using the BLAST algorithm against the GenBank database of the NCBI (www.ncbi.nlm.nih.gov).

\section{RESULTS}

In the initial experiments, fragments of NLV polyprotein gene were successfully amplified for 
all known NLV-infected samples of narcissus cv. 'Hawera'. Application of both NLs1-NLa1 and NLs1-NLVCPR2 primer pairs resulted in amplification of singular PCR products of expected size (669 bp and $1295 \mathrm{bp}$, respectively). The virus was detected in both leaf and bulb samples. No PCR products were amplified from healthy control plants or in water blanks.

To check whether the newly designed oligonucleotides would be useful for reliable detection of a wide range of NLV isolates by RT-PCR, additional experiment was performed with the field narcissus samples of cultivars 'Dutch Master' and 'Carlton'. The PCR products of the predicted length were obtained for 35\% samples of narcissus 'Dutch Master' and 5\% samples of narcissus 'Carlton'. Selected results of the experiment are shown in Fig. 1.

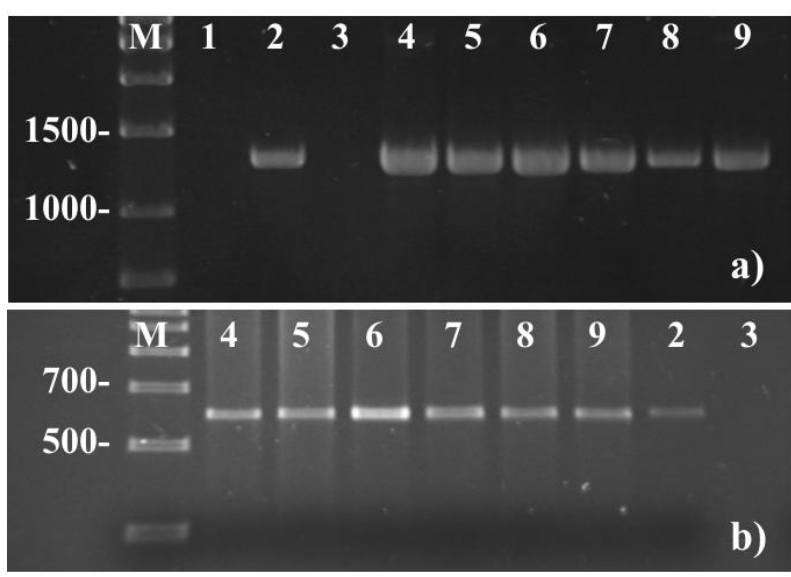

Figure 1. Agarose gel electrophoresis of amplification products obtained for NLV-infected leaves of narcissus plants using RT-PCR assay with: a) NLs1-NLVCPR2 or b) NLs1-NLa1 primer pairs. 1 - water blank, lane 2 NLV reference isolate (Applied Plant Research - Flower Bulb Sector, Lisse, The Netherlands), lane 3 - healthy narcissus 'Dutch Master', lanes 4-6 - NLV isolates from narcissus 'Hawera', lanes 7-8 - NLV isolates from narcissus 'Dutch Master', lane 9 - NLV isolate from narcissus 'Carlton'; M - 1 kb DNA Marker (Axygen BioScience Inc., USA)

The same leaf and bulb samples were tested simultaneously using DAS-ELISA with NLVspecific kit (data not shown). According to ELISA results, the virus was detected in all samples of cultivar 'Hawera', 5\% samples of cultivar 'Carlton' and only $15 \%$ samples of cultivar 'Dutch Master'.
Among NLV-positive samples, one was additionally infected with potyviruses and two - by NMV.

The specificity of obtained amplicons was confirmed by sequence analysis. The BLAST search against the GenBank database revealed that the nearest matches of the tested sequences were those for appropriate NLV sequences deposited under accession numbers U58770, DQ450199 or FJ024083. The percentage of nucleic acid identities among the CP gene sequences of tested as well as previously reported virus isolates was found to be between 95.6 and $99.8 \%$.

\section{DISCUSSION}

The results presented in this paper indicate that the designed primer pairs provide a specific test for the detection of NLV. Both primer pairs allowed amplifying products of expected sizes and their efficacy in PCR tests was proven with a panel of virus isolates. Since for diagnostic purposes a shorter amplicon would be preferable, it is suggested to use NLs1-NLa1 primer pair for routine NLV detection.

The need to eliminate NLV from cultivated narcissus has been postulated previously (Brunt 1977; Mowat et al. 1991). Although this pathogen alone usually induces inconspicuous leaf chlorosis, it probably contributes significantly to the decline of susceptible narcissus cultivars (Brunt 1977). To date, identification of NLV in narcissus plants was problematic. Firstly, NLV may be present either alone or with other viruses in naturally infected narcissus plants and it is difficult to correlate specific leaf symptoms with NLV infection. Moreover, leaf symptoms in some narcissus cultivars may initially be mistaken for those of Narcissus yellow stripe virus or Narcissus tip necrosis virus (Brunt 1977).

Secondly, the number and availability of NLV-specific commercial antibodies is limited (i.e., BQ, Lisse, The Netherlands, has stopped the production of NLV antisera), what restricts the application of serological assays for NLV diagnosis. In our experiments application of DAS-ELISA and RT-PCR resulted in detection of the virus in the same number of samples taken from narcissus 'Hawera' and 'Carlton'. However, NLV was de- 
tected using ELISA in only $43 \%$ of PCR-positive samples, collected from cultivar 'Dutch Master'. The differences in virus detectability using those two techniques might be due to the generally higher sensitivity of nucleic acids-based methods in comparison with serological ones (Komínek and Bryxiová 2005; Webster et al. 2004). Previous research, performed on a limited number of virus isolates, indicated that NLV isolates seem to be antigenically similar to each other (Mowat et al. 1991). However, studies that are more comprehensive are needed to define serological properties of the virus isolates.

The application of RT-PCR with newly designed primers seems to have the potential to help overcome the NLV detection problems. The assay allowed the specific detection of NLV isolates from narcissus plant material with better efficiency than ELISA method. When compared to the previously reported RT-PCR detection assay based on generic potyvirus primers, the method described in this paper provide a more rapid and specific detection of NLV.

\section{Acknowledgement}

This study was partly supported by the National Centre for Research and Development, Poland (project NR12 0063 06/2009).

\section{REFERENCES}

Asjes C.J. 1996. Control situation of virus diseases in narcissus in the Netherlands. Acta Hort. 432: 166174.

Berniak H., Malinowski T., Kamińska M. 2010. Characterization of polyclonal antibodies raised against two isolates of Cucumber mosaic virus. J. Plant Pathol. 92: 231-234.

Boom R., Sol C.J.A., Salimans M.M.M., Jansen C.L., Wertheim-van Dillen P.M.E., van der Noordaa J. 1990. Rapid and simple method for purification of nucleic acids. J. Clin. Microbiol. 28: 495-503.

Brunt A.A. 1977. Some hosts and properties of narcissus latent virus, a carlavirus commonly infecting narcissus and bulbous iris. Ann. Appl. Biol. 87: 355-364.

Brunt A.A. 1995. Bulb and corm crops. Narcissus. In: . Loebenstein G., Lawson R.H., Brunt A.A., (eds), Virus and virus-like diseases of bulb and flower crops. J. Wiley \& Sons, Chichester, UK, pp. 322334.

Brunt A.A., Atkey P.T. 1967. Rapid detection of narcissus yellow stripe and two other filamentous viruses in crude negatively-stained narcissus sap. Report of the Glasshouse Crop Research Institute for 1966, Dundee, UK, pp. 155-159.

Chen J., Chen J., Adams M.J. 2001. A universal PCR primer to detect members of the Potyviridae and its use to examine the taxonomic status of several members of the family. Arch. Virol. 146: 757-766.

Clark M.F., Lister R.M., Bar-Joseph M. 1988. ELISA Techniques. In: Weissbaum A., Weissbaum H. (eds), Methods for Plant Molecular Biology. Academic Press, pp. 507-530.

Clark V.R., Guy P.L. 2000. Five viruses in Narcissus spp. plants from New Zealand. Australasian Plant Pathol. 29: 227-229.

Derks A.F.L.M., Hollinger T.H.C., Vink-van den Abeele J.L. 1985. Identification and symptom expression of four elongated viruses infecting bulbous irises. Acta Hort. 164: 309-318.

Hanks G.R. 1993. Narcissus. In: De Hertogh A.A., Le Nard M. (eds), The physiology of flower bulbs. Elsevier, Amsterdam, The Netherlands, pp 463558.

Komínek P., Bryxiová A. 2005. Comparison of three techniques for detection of grapevine leafrollassociated virus 1. Acta Virol. 49: 37-43.

Malinowski T. 1996. Silica capture-reverse transcription-polymerase chain reaction (SC-RT-PCR): application for the detection of several plant viruses. Proc. $4^{\text {th }}$ Intern. EFPP Symp. Bonn, Germany, 912 September 1996, pp. 445-448.

Mowat W.P., Dawson S., Duncan G.H., Robinson D.J. 1991. Narcissus latent, a virus with filamentous particles and novel combination of properties. Ann. Appl. Biol. 119: 31-46.

Sochacki D. 2011a. The use of ELISA in the micropropagation of virus-free Narcissus. Acta Hort.. 886: 253-258.

Sochacki D. 2011b. Preservation of Polish varieties of narcissi (Narcissus L.) in field collection and in vitro cultures. Proc. Eur. Plant Genetic Res. Conf. Wageningen, The Netherlands, 5-7 April 2011, p. 104.

Webster C.G., Wylie S.J., Jones M.G.K. 2004. Diagnosis of plant viral pathogen. Curr. Sci. 86: 1604-1607.

Wei T., Pearson M.N., Cohen D. 2007. First report of Narcissus latent virus in New Zealand. Plant Pathol. 56: 720. 